\section{SM Journal of}

Hepatitis Research

\section{and Treatment}

\section{Article Information}

Received date: Jun 07, 2016

Accepted date: Jul 05, 2016

Published date: Jul 08, 2016

*Corresponding author

Shwu-Chen Tsay, Department of Chemistry and Frontier Research Center on Fundamental \& Applied Sciences of Matters, National Tsing Hua University, Taiwan, Email: tsay.susan@gmail.com

Distributed under Creative Commons CC-BY 4.0

Keywords Coumarin; Heterocycles; Methylenethio linker; Conjugates; Anti$\mathrm{HCV}$; Structure-activity relationship

Article DOI 10.36876/smjhrt.1009

\title{
New Conjugated Compounds Coming On Stream against Hepatitis C Virus
}

\author{
Shwu-Chen Tsay ${ }^{1 *}$, Wen-Chieh Huang ${ }^{1}$, Johan Neyts ${ }^{2}$ and Jih Ru Hwu ${ }^{1}$ \\ ${ }^{1}$ Department of Chemistry and Frontier Research Center on Fundamental \& Applied Sciences of Matters, \\ National Tsing Hua University, Taiwan \\ ${ }^{2}$ Rega Institute for Medical Research, Katholieke Universiteit Leuven, Belgium
}

\section{Abstract}

New conjugated compounds containing the coumarin moiety attached to mono- or bis-heterocyles have been synthesized. In $>100$ new conjugates of five categories, some of them exhibit significant and appealing activity against Hepatitis $\mathrm{C}$ Virus ( $\mathrm{HCV}$ ). The heterocycles therein include adenine, benzimidazole, benzothiazole, benzoxazole, guanine, hypoxanthine, imidazole, imidazopyridine, and purine. Use of the thiomethylene $\left(-\mathrm{SCH}_{2}-\right)$ linker to connect a coumarin moiety and a purine or imidazole nucleus leads to the conjugates with greater activity and selectivity than others. Various substituents, including $\mathrm{CH}_{3}, \mathrm{~F}, \mathrm{Cl}, \mathrm{Br}, \mathrm{OCH}_{3}, \mathrm{OAc}, \mathrm{CO}_{2} \mathrm{H}, \mathrm{COPh}, \mathrm{NO}_{2}$, $\beta$-D-glucose, and $\beta$-D-ribofuranose, are also attached to the core nuclei. Incorporation of a halogen substituent (particularly the $\mathrm{Br}$ ) onto the coumarin nucleus generally enhances the anti-HCV activity from double-digit to single-digit of $\mu \mathrm{M}$ potency. The structure-activity relationship is established, which is of value to the development of new anti-HCV drugs.

\section{Introduction}

Hepatitis C Virus (HCV), belonging to the family Flaviviradae, is a small enveloped (+)-RNA virus. About 150 million individuals have been infected with chronic HCV and about 4 million new cases occur annually [1]. The traditional treatment involves the use of interferon $\alpha-2$ alone or its combination with Ribavirin [2,3]. In 2011, two HCV protease inhibitors (i.e., boceprevir and telaprevir) were first approved for the treatment of HCV genotype 1 in combination with peg-interferon $\alpha$ and ribavirin. Though they can significantly increase the overall cure rates [4,5], some substantial adverse effects still exist [6]. Lately, Harvoni" (ledipasvir/sofosbuvir), simeprevir, sofosbuvir, daclatasvir, Viekira Pak" (ombitasvir/paritaprevir/ritonavirtablet; dasabuvir tablet), and Zepatier"' (elbasvir/grazoprevir) were approved by the U.S. Food and Drug Administration [7-10]. These new drugs, however, are highly costly for the intervention of HCV infections [11]. Thus the development and syntheses of new chemical entities with safer and lower price than the existing drugs to combat the HCV disease is at current need.

\section{Discussion}

Since 2008, Hwu, Neyts, Tsay, et al. have progressively published a series of articles [1217] related to heterocycle-coumarin conjugates as new agents against HCV. There are over 100 conjugates designed and synthesized, which can be divided into five categories as shown in Figure 1.

To bring up the conjugates, a direct linkage called "hinged" (i.e., Group 1) and a newly invented thiomethylene (- $\left.\mathrm{SCH}_{2}-\right)$ linker (i.e., Groups $\left.2-5\right)$ between the heterocycle and coumarin nuclei are adopted. The heterocyclic rings therein include benzimidazole ( 1 and 2$)$, benzoxazole $(3, X=O)$, benzothiazole $(3, X=S)$, imidazopyridine $(4, X=C H, Y=Z=H)$, purine $(4, X=N, Y=Z=H)$, adenine $\left(4, X=N, Y=\mathrm{NH}_{2}, Z=H\right)$, hypoxanthine $(4, X=N, Y=O H, Z=H)$, guanine $(4, X=N, Y$ $=\mathrm{OH}, \mathrm{Z}=\mathrm{NH}_{2}$ ), and imidazole (5). Moreover, different substituents, such as $\mathrm{CH}_{3}$, halogen, $\mathrm{OCH}_{3}$, $\mathrm{OAc}, \mathrm{CO}_{2} \mathrm{H}, \mathrm{COPh}, \mathrm{NO}_{2}, \beta$-D-glucose, and $\beta$-D-ribofuranose, are attached to the core nuclei. On the basis of their molecular frameworks and anti-viral activities, conclusive structure-activity relationship has been established for the betterment of heterocycle-coumarin type conjugates as anti-HCV therapeutics. The valuable information will contribute to the development of new drugs for a large number of patients.

Out of these $\sim 100$ compounds in five compound libraries, the conjugates with SI values $>10$ are picked up to list in Table in comparison with their parent conjugates and corresponding nucleoside derivatives. In Group 1, the conjugated compound having $\mathrm{R}^{1}=\mathrm{R}^{2}=\mathrm{CH}_{3}, \mathrm{R}^{3}=\mathrm{R}^{4}=\mathrm{R}^{5}=\mathrm{R}^{6}=\mathrm{R}^{7}=\mathrm{H}$ exhibits the most prominent anti-viral activity $\left(\mathrm{EC}_{50}=3.0 \mu \mathrm{M}\right)$ with a relatively poor SI value of 7.9. Addition of a substituent such as $\mathrm{CH}_{3}$ or $\mathrm{Br}$ into the coumarin nucleus or introduction of a $\beta$-Dribofuranose moiety to the benzimidazole ring does not improve their anti-HCV profile. Thus none of the hinged conjugates $\mathbf{1}$ is enrolled into the campaign for future development. Replacement of the hinged joint with a $-\mathrm{SCH}_{2}$ - linker to form conjugated compounds in Group 2 can significantly enhance the SI values. Successful examples include conjugates $2 \mathbf{b}-\mathbf{e}$ with $\mathrm{EC}_{50}=2.3 \sim 4.1 \mu \mathrm{M}$ and 

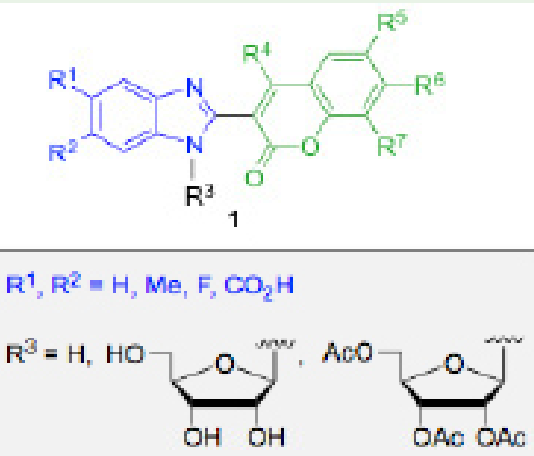

$\mathrm{R}^{4}, \mathrm{R}^{5}, \mathrm{R}^{6}, \mathrm{R}^{7}=\mathrm{H}, \mathrm{Me}, \mathrm{Br}, \mathrm{OMe}, \mathrm{OAC}, \mathrm{NO}$

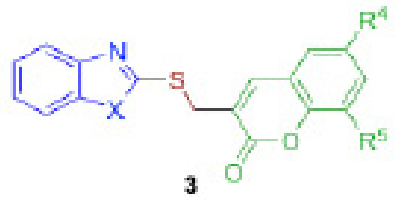

$$
\begin{aligned}
& X=O \text { or } S \\
& R^{4}, R^{5}=H, B r, O M e
\end{aligned}
$$
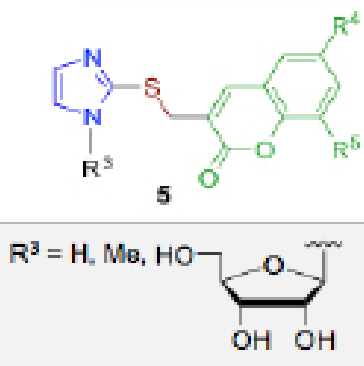

$\mathrm{R}^{4}, \mathrm{R}^{5}=\mathrm{H}, \mathrm{Me}, \mathrm{F}, \mathrm{Cl}, \mathrm{Br}, \mathrm{OMe}$

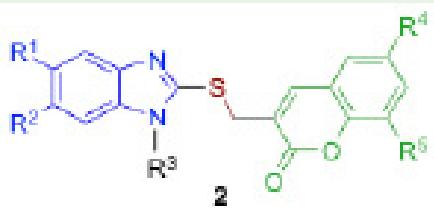

$\mathrm{R}^{3}, \mathrm{R}^{2}=\mathrm{H}, \mathrm{Me}, \mathrm{F}, \mathrm{Cl}, \mathrm{COPh}$

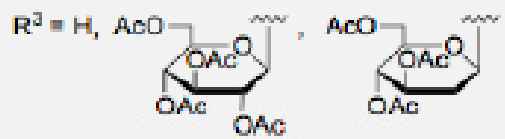

$\mathrm{R}^{4}, \mathrm{R}^{5}=\mathrm{H}, \mathrm{Br}, \mathrm{OMe}$

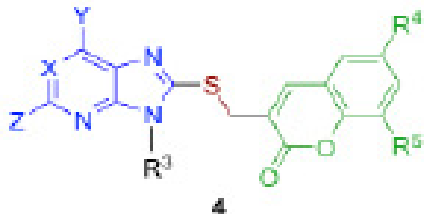

$X=\mathrm{CH} \propto r \mathrm{~N}, Y=\mathrm{H}_{3} \mathrm{NH}_{2}$ or OH, Z $=\mathrm{H} \propto r \mathrm{NH}_{2}$

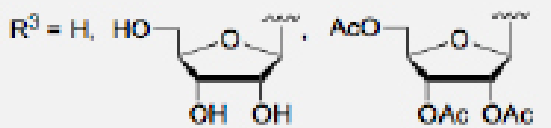

$\mathrm{R}^{4}, \mathrm{R}^{5}=\mathrm{H}, \mathrm{Me}, \mathrm{F}, \mathrm{Cl}, \mathrm{Br}, \mathrm{OMe}$

Figure 1: General structure of five categories of heterocycle-coumarin conjugates.

SI $=10 \sim 19$, which display greater activity and selectivity than their parent compound $\mathbf{2 a}$. Introduction of a peracetyl $\beta$-D-glucose moiety onto the benzimidazole nucleus to give the resultant glycoside-type conjugates maintains the same order of activity and selectivity as their kin ( $\mathbf{2 b}$ versus $\mathbf{2 d}$ and $\mathbf{2 c}$ versus $\mathbf{2 e}$ ).

For investigation of the influence resulting from heteroatoms in a five-membered nucleus (i.e., the imidazole part), one nitrogen atom in benzimidazole nucleus is replaced with an oxygen or a sulfur atom. The resultant benzoxazole-containing conjugate $\mathbf{3 b}$ possesses an appealing selectivity index value $(\mathrm{SI}=11)$ by addition of a $\mathrm{Br}$ substituent onto the coumarin nucleus of parent conjugate $\mathbf{3 a}$. The enhancement of the SI value comes from the reduction of cytotoxicity of the compound. Furthermore, one or two carbon atoms in the aromatic ring of benzimidazole nucleus are replaced with one or two nitrogen atoms to yield imidazopyridine-containing conjugates (4a and $\mathbf{4 b}$ ) as well as purine-containing conjugate $(\mathbf{4 c})$, respectively. The conjugated compound with the purine nucleus $\left(4 \mathrm{c}, \mathrm{EC}_{50}=2.0 \mu \mathrm{M}, \mathrm{SI}\right.$ =54) has a much higher selectivity than those with a benzimidazole, benzoxazole, benzothiazole, or imidazopyridine nucleus due to lower cytotoxicity. On the other hand, addition of a Br substituent onto the

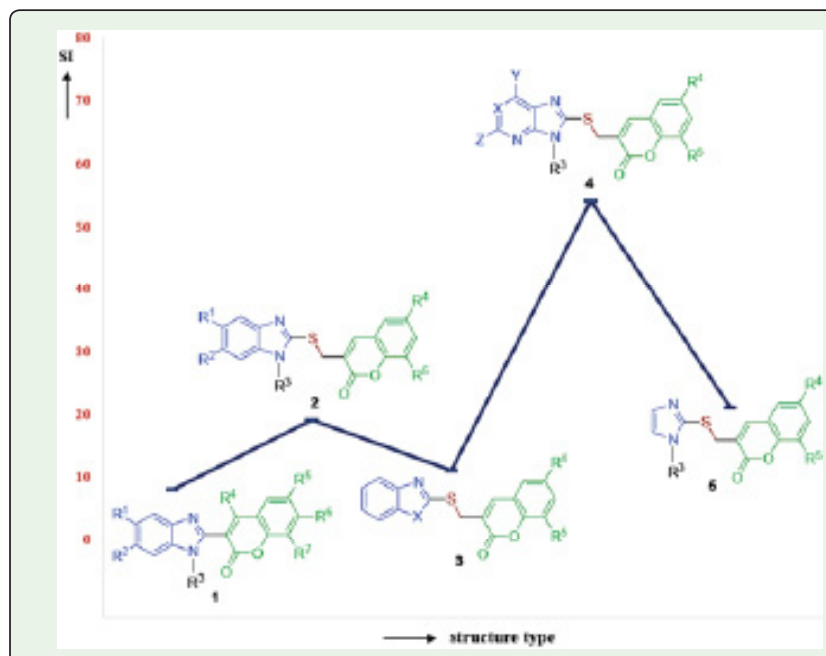

Figure 2: Relative relationship between heterocycle-coumarin conjugates 1-5 and their associated selectivity index values $(\mathrm{SI}=$ selectivity index, ratio of $\mathrm{CC}_{50}$ to $\mathrm{EC}_{50}$ ). 
Table 1: Antiviral effect of conjugated compounds on HCV 1b subgenomic replicon replication in Huh 5-2 cells.

\begin{tabular}{|c|c|c|c|c|c|c|c|c|c|c|c|}
\hline Compound & $\mathbf{R}^{1}$ & $\mathbf{R}^{2}$ & $\mathbf{R}^{3}$ & $\mathbf{R}^{4}$ & $\mathbf{R}^{5}$ & $\mathbf{x}$ & $\mathbf{Y}$ & $\mathbf{Z}$ & $\mathrm{CC}_{50}{ }^{\mathrm{a}}(\mu \mathrm{M})$ & $\mathrm{EC}_{50}^{\mathrm{b}}(\mu \mathrm{M})$ & $\mathbf{S I}^{\mathrm{c}}$ \\
\hline $2 a$ & $\mathrm{H}$ & $\mathrm{H}$ & $\mathrm{H}$ & $\mathrm{H}$ & $\mathrm{H}$ & - & - & - & 90 & 27 & 3.4 \\
\hline $2 b$ & $\mathrm{H}$ & $\mathrm{H}$ & $\mathrm{H}$ & $\mathrm{Br}$ & $\mathrm{H}$ & - & - & - & 42 & 4 & 10 \\
\hline $2 c$ & $\mathrm{Cl}$ & $\mathrm{Cl}$ & $\mathrm{H}$ & $\mathrm{Br}$ & $\mathrm{H}$ & - & - & - & 44 & 2.3 & 19 \\
\hline $2 d$ & $\mathrm{H}$ & $\mathrm{H}$ & $\begin{array}{c}\text { peracetyl } \\
\beta \text {-D-glucose }\end{array}$ & $\mathrm{Br}$ & $\mathrm{H}$ & - & - & - & 43 & 4.1 & 10 \\
\hline $2 e$ & $\mathrm{Cl}$ & $\mathrm{Cl}$ & $\begin{array}{c}\text { peracetyl } \\
\beta \text {-D-glucose }\end{array}$ & $\mathrm{Br}$ & $\mathrm{H}$ & - & - & - & $>64.8$ & 4.1 & $>16$ \\
\hline $3 b$ & $\mathrm{H}$ & $\mathrm{H}$ & - & $\mathrm{Br}$ & $\mathrm{H}$ & $\mathrm{O}$ & - & - & 131 & 12 & 11 \\
\hline $4 a$ & - & - & $\mathrm{H}$ & $\mathrm{H}$ & $\mathrm{H}$ & $\mathrm{CH}$ & $\mathrm{H}$ & $\mathrm{H}$ & 95 & 59 & 1.6 \\
\hline $4 b$ & - & - & $\mathrm{H}$ & $\mathrm{Br}$ & $\mathrm{H}$ & $\mathrm{CH}$ & $\mathrm{H}$ & $\mathrm{H}$ & 128 & 6.8 & 19 \\
\hline $4 c$ & - & - & $\mathrm{H}$ & $\mathrm{H}$ & $\mathrm{H}$ & $\mathrm{N}$ & $\mathrm{H}$ & $\mathrm{H}$ & 109 & 2.0 & 54 \\
\hline $4 d$ & - & - & $\beta$-D-ribofuranose & $\mathrm{H}$ & $\mathrm{H}$ & $\mathrm{N}$ & $\mathrm{H}$ & $\mathrm{H}$ & 50 & 5.5 & 9.1 \\
\hline $4 e$ & - & - & $\beta$-D-ribofuranose & $\mathrm{H}$ & $\mathrm{H}$ & $\mathrm{N}$ & $\mathrm{NH}_{2}$ & $\mathrm{H}$ & 49 & 28 & 1.7 \\
\hline $5 a$ & - & - & $\mathrm{H}$ & $\mathrm{H}$ & $\mathrm{H}$ & - & - & - & 122 & 30 & 4.1 \\
\hline $5 b$ & - & - & $\mathrm{H}$ & $\mathrm{F}$ & $\mathrm{H}$ & - & - & - & 83 & 7.2 & 12 \\
\hline $5 c$ & - & - & $\mathrm{H}$ & $\mathrm{Br}$ & $\mathrm{H}$ & - & - & - & 75 & 5.1 & 15 \\
\hline $5 d$ & - & - & $\mathrm{H}$ & $\mathrm{H}$ & $\mathrm{OCH}_{3}$ & - & - & - & 173 & 8.4 & 21 \\
\hline $5 e$ & - & - & $\beta$-D-ribofuranose & $\mathrm{H}$ & $\mathrm{H}$ & - & - & - & 128 & 59 & 2.2 \\
\hline
\end{tabular}

aThe concentration of a compound with an adverse effect of $50 \%$ was observed on the host cell metabolism, as determined by the MTS method. ${ }^{\mathrm{b}}$ The concentration of a compound at which virus replication was inhibited by $50 \%$ was observed, as determined by real-time quantitative $\mathrm{RT}-\mathrm{PCR}$. ${ }^{\mathrm{c} S e l e c t i v i t y}$ index $\left(\mathrm{ratio}\right.$ of $\mathrm{CC}_{50}$ to $\mathrm{EC}_{50}$ ).

coumarin nucleus of parent imidazopyridine-containing conjugate $\mathbf{4 a}$ gives the conjugate $\mathbf{4} \mathbf{b}$, which gains significant increment of anti-HCV activity with $\mathrm{EC}_{50}=6.8 \mu \mathrm{M}$ and $\mathrm{SI}=19$. In contrast, incorporation of a $\beta$-D-ribofuranose moiety onto the purine nucleus reduces the selectivity (i.e., $4 \mathrm{~d}, \mathrm{EC}_{50}=5.5 \mu \mathrm{M}, \mathrm{SI}=9.1$ ). It is due to the increment of cytotoxicity. Furthermore, introduction of an $\mathrm{NH}_{2}$ or $\mathrm{OH}$ substituent onto the purine nucleus to form adenosine-, inosine-, or guanosine-coumarin conjugates (e.g., $\mathbf{4 e}$ and $\mathbf{4 f}$ ) does not increase their SI values owing to the lower potency they exhibit.

Finally, the heterobicycle nucleus of conjugates is simplified to monocyclic nucleus by elimination of the aromatic ring. The resultant imidazole-coumarin conjugates $\mathbf{5 b}-\mathbf{d}$ with $\mathrm{EC}_{50}=5.1 \sim 8.4 \mu \mathrm{M}$ and $\mathrm{SI}=12 \sim 21$ can acquire increasing anti-viral activity and selectivity through incorporation of an $\mathrm{F}, \mathrm{Br}$, or $\mathrm{OCH}_{3}$ substituent onto the parent conjugate $\mathbf{5 a}$. Nevertheless, modification of the imidazole nucleus with a $\beta$-D-ribofuranose moiety cannot better the anti-HCV potency (cf. 5e).

The conjugated compounds in this report primarily involve three elements: linkers, coumarin, and heterocycles. Through systematic modifications and derivatization of these key elements, the heterocycle-coumarin conjugates with the optimized selectivity for every category are obtained. Accordingly, their representative scaffold versus SI value is plotted in Figure 2. The purine-coumarin conjugates $\mathbf{4}$ have a higher position than other conjugates and could be held an ideal scaffold in the development of anti-HCV therapeutics. Furthermore, we draw the following structure-activity relationship on the basis of their $\mathrm{EC}_{50}, \mathrm{CC}_{50}$, and SI values.

1. Adoption of the thiomethylene linker $\left(-\mathrm{SCH}_{2}-\right)$ as a joint to construct heterocycle-coumarin conjugates is a better choice than the hinged connection.

2. Incorporation of a halogen substituent (particularly the $\mathrm{Br}$ atom) onto the coumarin nucleus generally enhances the anti-HCV activity from double-digit to single-digit of $\mu \mathrm{M}$ potency.
3. Enhancement of the selectivity index values resulting from the heterocycle nucleus follows the order: purine > imidazole $>$ benzimidazole, imidazopyridine, benzoxazole > adenine, hypoxanthine, guanine, benzothiazole.

4. Replacement of the hydrogen atom in the heterocyclic ring with a $\beta$-D-glucose or $\beta$-D-ribofuranose displays a slim or no effect on the HCV inhibition.

\section{Conclusion}

Systematic investigation of the structure-activity relationship on various heterocycle-coumarin conjugates against HCV is illustrated. In these compound libraries, conjugates bearing a simple purine or imidazole nucleus exhibit better anti-HCV activity and selectivity than their derivatives. Moreover, a $-\mathrm{SCH}_{2}-$ linker used as the joint between the heterocycle and coumarin nuclei is crucial to the design. Use of these findings leads a legitimate way to optimize the anti-HCV profile of these conjugated compounds.

\section{Acknowledgement}

For financial support, we thank Ministry of Science and Technology of R.O.C. (grant Nos. NSC102-2633-M-007-001 and MOST 103-2113-M-007-018-MY3), Ministry of Education of R.O.C. (grant Nos. 105N501CE1 and 105N506CE1), and National Central University (grant No. 103G603-14). The work in Leuven is supported by the European Commission SILVER project within the $7^{\text {th }}$ Framework Program as Cooperation Project Grant Agreement (No. 260644).

\section{References}

1. Murphy DG, Sablon E, Chamberland J, Fournier E, Dandavino R, Tremblay $\mathrm{CL}$. Hepatitis $\mathrm{C}$ virus genotype 7 , a new genotype originating from central Africa. J Clin Microbiol. 2015; 53: 967-972.

2. Oze T, Hiramatsu N, Mita E, Akuta N, Sakamoto N, Nagano H, et al. A multicenter survey of re-treatment with pegylated interferon plus ribavirin 
combination therapy for patients with chronic hepatitis C in Japan. Hepato Res. 2013; 43: 35-43.

3. Kwong AD, Kauffman RS, Hurter P, Mueller P. Discovery and development of telaprevir: an NS3-4A protease inhibitor for treating genotype 1 chronic hepatitis C virus. Nat Biotechnol. 2011; 29: 993-1003

4. Thibault PA, Wilson JA. Targeting miRNAs to treat Hepatitis $C$ Virus infections and liver pathology: Inhibiting the virus and altering the host. Pharmacol Res. 2013; 75: 48-59

5. Hulskotte EG, Feng HP, Xuan F, Gupta S, van Zutven MG, O'Mara E, et al. Pharmacokinetic evaluation of the interaction between hepatitis $C$ virus protease inhibitor boceprevir and 3-hydroxy-3-methylglutaryl coenzyme A reductase inhibitors atorvastatin and pravastatin. Antimicrob Agents Chemother. 2013; 57: 2582-2588.

6. Orrin E, Barnabas A, Agarwal K, Walsh SA. Cutaneous side-effects of ant hepatitis C treatment: the U.K. experience. Br J Dermatol. 2015; 172: 292

7. Wanchoo R, Thakkar J, Schwartz D, Jhaveri KD. Harvoni (Ledipasvir with Sofosbuvir)-Induced Renal Injury. Am J Gastroenterol. 2016; 111: 148-149.

8. Harrington PR, Fleischer R, Connelly SM, Lewis LL, Murray J. Ribavirin reduces absolute lymphocyte counts in hepatitis $C$ virus-infected patients treated with interferon-free, direct-acting antiviral regimens. Clin Infect Dis. 2015; 61: 974-977

9. Wyles DL, Ruane PJ, Sulkowski MS, Dieterich D, Luetkemeyer A, Morgan TR, et al. Daclatasvir plus Sofosbuvir for HCV in Patients Coinfected with HIV-1. N Engl J Med. 2015; 373: 714-725.
10. Keating GM. Elbasvir/Grazoprevir: First Global Approval. Drugs. 2016; 76 617-624

11. van de Ven N, Fortunak J, Simmons B, Ford N, Cooke GS, Khoo S, et al. Minimum target prices for production of direct-acting antivirals and associated diagnostics to combat hepatitis C virus. Hepatology. 2015; 61: 1174-1182.

12. Hwu JR, Singha R, Hong SC, Chang YH, Das AR, Vliegen I, et al. Synthesis of new benzimidazole-coumarin conjugates as anti-hepatitis $C$ virus agents. Antiviral Res. 2008; 77: 157-162.

13. Neyts J, De Clercq E, Singha R, Chang YH, Das AR, Chakraborty SK, et al. Structure-activity relationship of new anti-hepatitis $C$ virus agents: heterobicycle-coumarin conjugates. J Med Chem. 2009; 52: 1486-1490.

14. Hwu JR, Lin S-Y, Tsay S-C, Singha R, Pal BK, Leyssen P, et al. Development of new sulfur-containing conjugated compounds as anti-HCV agents. Phosphorus, Sulfur, Silicon, Relat Elem. 2011; 186: 1144-1152.

15. Hwu JR, Lin SY, Tsay SC, De Clercq E, Leyssen P, Neyts J. Coumarin-purine ribofuranoside conjugates as new agents against hepatitis $\mathrm{C}$ virus. J Med Chem. 2011; 54: 2114-2126.

16. Tsay SC, Hwu JR, Singha R, Huang WC, Chang YH, Hsu MH, et al Coumarins hinged directly on benzimidazoles and their ribofuranoside to inhibit hepatitis C virus. Eur J Med Chem. 2013; 63: 290-298.

17. Tsay SC, Lin S-Y, Huang W-C, Hsu M-H, Hwang KC, Lin, C-C, et al. Synthesis and structure-activity relationship of imidazole-coumarin conjugates against hepatitis C virus. Molecules. 2016; 21: 228-244. 